\title{
Spectrophotometric studies on some arylazo diamino pyrimidinol in organic solvents and in buffer solutions
}

\author{
Nadia Ahmed Abdalla *, Mohamed Tawfek El-Haty, \\ Farok Abd-Elkarim Adam and Fatma Wafdy Hassan \\ Chemistry Department, Aswan Faculty of Science, Aswan University, 81528, Aswan, Egypt \\ ${ }^{*}$ Corresponding author at: Chemistry Department, Aswan Faculty of Science, Aswan University, 81528, Aswan, Egypt. \\ Tel.: +2.097.2312411. Fax: +2.012.2811224. E-mail address: nadia_201071@yahoo.com (N.A. Abdalla).
}

\section{ARTICLE INFORMATION}

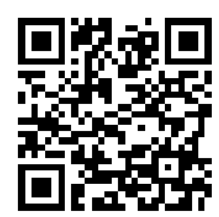

DOI: $10.5155 /$ eurjchem.5.1.41-52.825

Received: 09 May 2013

Received in revised form: 06 July 2013

Accepted: 26 July 2013

Online: 31 March 2014

\section{KEYWORDS}

\section{pK values}

Mixed solvents

Buffer solutions

Spectra behavior

Molecular complex

Arylazo diaminopyrimidinol

\section{Introduction}

Recent years have witnessed a great deal of interest in the synthesis of the pyrimidine compounds because of its higher $\pi$ acidity [1-3] than conventional widely used pyridine bases [4,5] and also due to its biochemical importance [6-11]. Pyrimidine is an active component of antibiotics, antimicrobials, anticonvulsants, antispasmatics, antineoplastics (e.g. bleomycin) and antidiabetogenics. Many of these derivatives had been used in seed dressing, crop-disease control and veterinary drugs.

Various reports had appeared recently discussing the electronic spectral properties of pyrimidine bases and their derivatives [12-23]. Pyrimidine is an active component of antibiotics and antineoplastics (e.g. Blemmycin). There is no work has been reported on the spectral and acid-base properties of azo 2,6-diaminopyrimidinol. It was observed that the presence of $\mathrm{OH}$ and/or $\mathrm{NH}_{2}$ groups in $\mathrm{C}-2$ and C-4 of arylazo pyrimidine have been found to exhibit various biological interest $[24,25]$ and exhibit antagonistic activity on nuclei acid metabolism [26,27]. The spectral properties of pyrimidine are great importance because these compounds play a role in photodenaturation of nucleic acid [28].
In view of the above observation, we considered it worthwhile to study the spectral behavior of some new azo compounds derived from 2,6-diaminopyrimidinol in pure and mixed organic solvents of various polarities. The $\mathrm{pH}$ effect is also included with the aim of elucidating the acid-base behavior as well as calculating the acidity constants of the compounds under investigation.

\section{Experimental}

\subsection{Azo dyes solution}

The azo dyes were synthesized by coupling the alkaline pyrimidines-ethanol mixture with the appropriate diazonium salt [29]. The diazotate were prepared by appropriate method for each amine.

The formed compounds were purified by repeated crystallization of the crude products from ethanol and dried in vacuum over silica gel. The purity of the compounds was checked by elemental analysis reported in Table 1 .

The azo compounds synthesized can be represented in Scheme 1. 
Table 1. Elemental analysis and formula weight (F.W.) of the prepared ligands.

\begin{tabular}{|c|c|c|c|c|}
\hline \multirow[t]{2}{*}{ Compound } & \multirow{2}{*}{$\begin{array}{l}\text { Molecular formula } \\
\text { (M.wt., g) }\end{array}$} & \multicolumn{3}{|c|}{ Calcd. (Found) \% } \\
\hline & & $\mathbf{C}$ & $\mathbf{H}$ & $\mathbf{N}$ \\
\hline $\mathrm{L}_{1}(p-\mathrm{OH})$ & $\mathrm{C}_{10} \mathrm{H}_{10} \mathrm{~N}_{6} \mathrm{O}_{2}(246)$ & $48.78(48.80)$ & $4.07(4.10)$ & 34.15 (34.15) \\
\hline $\mathrm{L}_{2}\left(p-\mathrm{HSO}_{3}\right)$ & $\mathrm{C}_{10} \mathrm{H}_{10} \mathrm{~N}_{6} \mathrm{O}_{4} \mathrm{~S}(310)$ & $38.71(38.90)$ & $3.23(3.30)$ & $27.09(27.10)$ \\
\hline $\mathrm{L}_{3}(o-\mathrm{COOH})$ & $\mathrm{C}_{11} \mathrm{H}_{10} \mathrm{~N}_{6} \mathrm{O}_{3}(274)$ & $48.18(47.48)$ & $3.65(3.56)$ & $30.66(31.02)$ \\
\hline $\mathrm{L}_{4}\left(o-\mathrm{CH}_{3}\right)$ & $\mathrm{C}_{11} \mathrm{H}_{12} \mathrm{~N}_{6} \mathrm{O}(244)$ & $54.10(54.08)$ & $4.92(5.01)$ & $34.43(34.30)$ \\
\hline $\mathrm{L} 5\left(p-\mathrm{N}, \mathrm{N}-\left(\mathrm{C}_{2} \mathrm{H}_{5}\right)_{2} \mathrm{~N}\right)$ & $\mathrm{C}_{14} \mathrm{H}_{19} \mathrm{~N}_{7} \mathrm{O}(301)$ & $55.81(55.90)$ & $6.31(6.32)$ & $32.56(32.60)$ \\
\hline $\mathrm{L}_{6}(\mathrm{Ar}=\mathrm{Naphthyl})$ & $\mathrm{C}_{14} \mathrm{H}_{12} \mathrm{~N}_{6} \mathrm{O}(280)$ & $60.00(60.20)$ & $4.29(4.40)$ & $30.00(30.09)$ \\
\hline $\mathrm{L}_{7}\left(p-\mathrm{NO}_{2}\right)$ & $\mathrm{C}_{10} \mathrm{H}_{9} \mathrm{~N}_{7} \mathrm{O}_{3}(275)$ & $43.64(43.61)$ & $3.27(3.25)$ & $35.64(35.62)$ \\
\hline$\underline{\mathrm{L}_{8}(\mathrm{H})}$ & $\mathrm{C}_{10} \mathrm{H}_{10} \mathrm{~N}_{6} \mathrm{O}(230)$ & $52.17(52.20)$ & $4.35(4.38)$ & $36.52(36.51)$ \\
\hline
\end{tabular}<smiles>[X]c1ccc(/N=N/c2c(N)nc(N)nc2O)cc1</smiles>

5-(4-Hydroxy-phenylazo)-2,6-diamino-4-pyrimidinol $\left(\mathrm{L}_{1}\right) \mathrm{X}=p$-OH 5-(4-Sulphonic acid-phenylazo)-2,6-diamino-4-pyrimidinol $\left(\mathrm{L}_{2}\right) \mathrm{X}=p-\mathrm{HSO}_{3}$ 5-(2-Carboxylic acid-phenylazo)-2,6-diamino-4-pyrimidinol ( $\left.\mathrm{L}_{3}\right) \mathrm{X}=o-\mathrm{COOH}$ 5-(2-Methyl-phenylazo)-2,6-diamino-4-pyrimidinol ( $\left.\mathrm{L}_{4}\right) \mathrm{X}=o-\mathrm{CH}_{3}$

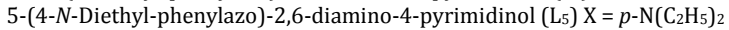

5-(Naphylazo)-2,6-diamino-4-pyrimidinol $\left(\mathrm{L}_{6}\right) \mathrm{Ar}=$ naphthyl

5-(4-Nitro-phenylazo)-2,6-diamino-4-pyrimidinol ( $\left.\mathrm{L}_{7}\right) \mathrm{X}=p$ - $\mathrm{NO}_{2}$ 5-(Phenylazo)-2,6-diamino-4-pyrimidinol $\left(\mathrm{L}_{8}\right) \mathrm{X}=-\mathrm{H}$

Scheme 1

\subsection{Organic solvents}

A stock solutions $\left(1.0 \times 10^{-3} \mathrm{~mol} / \mathrm{dm}^{3}\right)$ of the investigate azo dyes were prepared by dissolving the accurately weighed amount of each in the required spectral grade solvent. The organic solvents cyclohexane $\left(\mathrm{C}_{6} \mathrm{H}_{12}\right)$, ethanol $(\mathrm{EtOH})$, methanol $(\mathrm{MeOH})$, chloroform $\left(\mathrm{CHCl}_{3}\right)$, carbon tetrachloride $\left(\mathrm{CCl}_{4}\right)$, dimethylformamide (DMF) and dimethylsulphoxide (DMSO) used were of spectral grade (BDH or Merck) products.

\subsection{Universal buffer solutions}

The modified aqueous universal buffer series $(\mathrm{pH}=2.39$ 13.1) were prepared according to method [30]. The measurements of the $\mathrm{pH}$ values of those buffer solutions were corrected using the relation $\mathrm{pH}^{*}=\mathrm{pH}(\mathrm{R})-\delta$, where $\mathrm{pH}$ is the corrected reading and $\mathrm{pH}(\mathrm{R})$ is the $\mathrm{pH}$ meter reading obtained in waterorganic solvent mixtures. The value of $\delta$ for aqueous buffer solution containing organic solvents used was determined according to Douheret [31].

\subsection{Instrumentation}

The $\mathrm{pH}$ meter was carried out using KL-016 pH METER digital $\mathrm{pH}$-Messgerate, accurate to \pm 0.005 unit. The electrode system was calibrated before and after a series of measurements using standard buffer solutions at pH's 4.0, 7.0 and 9.0. The absorption spectra of the UV and visible regions were recorded on Shimadzu UV-1650 PC, UV-Visible Recording Spectrophotometer using $1 \mathrm{~cm}$ silica cell.

\section{Results and discussion}

\subsection{Electronic absorption spectra in pure ethanol}

The recorded electronic absorption spectra of azo compounds $\left(\mathrm{L}_{1}-\mathrm{L}_{8}\right)$ in pure ethanol are reported in Table 2. It is clear from the data are plotted in Figure 1 that, the spectra of all compounds studied in ethanol exhibit mainly four bands in the UV-visible region. It is possible to assign the absorption bands of the studied arylazopyrimidines in the basis of the information derived from the spectra of simple pyrimidine bases and their derivatives [32-36]. Thus, the UV spectral bands of the arylazo compounds under investigation may be viewed as perturbed benzene spectra. Thus, their electronic transitions can be assigned by considering how the appropriate substitution would affect the benzene spectral properties. The addition of two nitrogen atoms to benzene, such as pyrimidine perturbs the benzene $\pi$-electron cloud. Some authors suggested that the 210 and $200 \mathrm{~nm}$ bands of pyrimidine correspond to the $\mathrm{A}_{1 \mathrm{~g}} \rightarrow \mathrm{B}_{1 \mathrm{u}}, \mathrm{A}_{1 \mathrm{~g}} \rightarrow \mathrm{E}_{1 \mathrm{u}}$ transitions of benzene, respectively [37]. Other authors have calculated the electronic transitions for pyrimidine bases and showed the presence of out-of-plane $\left(\mathrm{n} \rightarrow \pi^{*}\right.$ and $\left.\pi \rightarrow \pi^{*}\right)$ transitions which occur at $295 \mathrm{~nm}\left(\mathrm{n} \rightarrow \pi^{*}\right)$ and $255 \mathrm{~nm}\left(\pi \rightarrow \pi^{*}\right)$ and in-plane $\left(\pi \rightarrow \pi^{*}\right.$ and $\left.\mathrm{n} \rightarrow \sigma^{*}\right)$ transitions are present at $243\left(\mathrm{~B}_{2 \mathrm{u}}\right)$ and $212 \mathrm{~nm}\left(\mathrm{~B}_{1 \mathrm{u}}\right)$, respectively [38]. In accordance with these considerations it is suggested that, in the present studies, the two UV bands located in the regions 207$270 \mathrm{~nm}$ range is wider than $221-250 \mathrm{~nm}$ can be attributed to the localization of $\pi$-electrons in pyrimidine ring and in the benzene ring respectively [39]. The influence of the positions of the second UV band by the nature of the substitiuent $(\mathrm{X})$, and their high molar absorptivities substantiate the $\pi \rightarrow \pi^{*}$ assignment.

Moreover, the location of the second UV band at longer wavelengths in case of compound $\mathrm{L}_{6}(\mathrm{Ar}=$ Naphthyl, $\lambda=268$ $\mathrm{nm})$ other than those for $\mathrm{L}_{8}(\mathrm{X}=-\mathrm{H}, \lambda=221 \mathrm{~nm})$ can be attributed to the high delocalization of $\pi$-electrons in the naphthyl moiety $\left(\mathrm{L}_{6}\right)$, which in line with the above assignment.

The third weak band observed at $269-279 \mathrm{~nm}$, can be assigned to the excitation of the non-bonding electrons from the lone pair of a nitrogen atom to an $\pi^{*}$ orbital of the ring [40]. The $n \rightarrow \pi^{*}$ assignment is confirmed by the spectral behavior of these compounds in aqueous buffer solutions of different $\mathrm{pH}$ values where the $n \rightarrow \pi^{*}$ band disappeared by protonation in acidic medium and thus, the excitation of n-electrons is expected to hindered.

In the visible region, the recorded spectra in ethanol show two broad bands within the range 321-382 $\mathrm{nm}$ and 404-449 $\mathrm{nm}$ (expected in case of $\mathrm{L}_{7}, \mathrm{X}=p-\mathrm{NO}_{2}$ and $\mathrm{L}_{8}, \mathrm{X}=-\mathrm{H}$ ). These two bands are highly influenced by the nature of substituent and type of organic solvent. 
Table 2. Electronic spectra sharacteristics of arylazopyrimidine derivatives in different pure organic solvents, $\lambda_{\max }(\mathrm{nm}) ; \varepsilon_{\max }\left(\times 10^{3} \mathrm{~mol}-1 \mathrm{~cm}^{2}\right) ;$ sh $=\operatorname{shoulder} ; \mathrm{br}$ = broad; w.b. = weak band.

\begin{tabular}{|c|c|c|c|c|c|c|c|c|c|c|c|c|c|c|}
\hline \multirow{2}{*}{$\begin{array}{l}\text { Compound } \\
\text { (X) } \\
\text { (Concentration) }\end{array}$} & \multicolumn{2}{|l|}{ DMSO } & \multicolumn{2}{|l|}{ DMF } & \multicolumn{2}{|l|}{$\mathrm{MeOH}$} & \multicolumn{2}{|l|}{ EtOH } & \multicolumn{2}{|l|}{$\mathrm{CHCl}_{3}$} & \multicolumn{2}{|l|}{$\mathrm{CCl}_{4}$} & \multicolumn{2}{|l|}{$\mathrm{C}_{6} \mathrm{H}_{12}$} \\
\hline & $\lambda_{\max }$ & $\varepsilon_{\max }$ & $\lambda_{\max }$ & $\varepsilon_{\max }$ & $\lambda_{\max }$ & $\varepsilon_{\max }$ & $\lambda_{\max }$ & $\varepsilon_{\max }$ & $\lambda_{\max }$ & $\varepsilon_{\max }$ & $\lambda_{\max }$ & $\varepsilon_{\max }$ & $\lambda_{\max }$ & $\varepsilon_{\max }$ \\
\hline $\mathrm{L}_{1}$ & - & - & - & - & 206 & 27.52 & 208 & 25.2 & - & - & - & - & 222 & 20.76 \\
\hline$(p-\mathrm{OH})$ & - & - & - & - & 250 & 7.52 & 250 & 7.2 & - & - & - & - & 251 & 6.64 \\
\hline$\left(5 \times 10^{-5}\right.$ & 276 & 6.58 & 277 & 5.5 & 274 & 5.82 & 274 & 5.52 & 274 & 6.08 & 277 & 6.2 & 275 & 5.84 \\
\hline \multirow[t]{2}{*}{$\mathrm{mol} / \mathrm{dm}^{3}$ ) } & 393 & 7.00 & 386 & 6.31 & 379 & 5.34 & 380 & 5.18 & 383 & 4.6 & 382 & 4.82 & 380 & 4.78 \\
\hline & 415 & 7.44 & 411 & 6.32 & 415 & 5.42 & 417 & 5.2 & 425 & 6.09 & 424 & 5.63 & 422 & 4.98 \\
\hline $\mathrm{L}_{2}$ & - & - & - & - & 207 & 40.08 & 207 & 39.44 & - & - & - & - & & - \\
\hline$\left(p-\mathrm{HSO}_{3}\right)$ & - & - & - & - & 224 & 22.7 & 225 & 22.64 & - & - & - & - & 226 & 22.26 \\
\hline$\left(5 \times 10^{-5}\right.$ & 277 & 2.59 & 277 & 2.23 & 274 & 3.74 & 274 & 3.6 & 276 & 2.97 & 276 & 2.88 & 275 & 3.9 \\
\hline \multirow[t]{2}{*}{$\mathrm{mol} / \mathrm{dm}^{3}$ ) } & 388 & 4.46 & 386 & 2.13 & 380 & 1.86 & 382 & 1.72 & 382 & 1.28 & 367 & 1.27 & 380 & 1.14 \\
\hline & $423 \mathrm{sh}$ & 2.86 & $428 \mathrm{sh}$ & 1.26 & $406 \mathrm{sh}$ & 1.42 & $415 \mathrm{sh}$ & 1.16 & $406 \mathrm{sh}$ & 1.18 & $407 \mathrm{sh}$ & 0.94 & $420 \mathrm{sh}$ & 0.6 \\
\hline $\mathrm{L}_{3}$ & - & - & - & - & 207 & 19.0 & 208 & 18.1 & - & - & - & - & 215 & 6.44 \\
\hline$(o-\mathrm{COOH})$ & - & - & - & - & 229 & 6.22 & $232 \mathrm{wb}$ & 6.42 & - & - & - & - & 234 & 4.9 \\
\hline$\left(5 \times 10^{-5}\right.$ & 273 & 9.84 & 273 & 8.42 & w.b & 6.2 & 268 w.b & 6.04 & 270 & 11.2 & 272 & 10.4 & w.b & 4.66 \\
\hline \multirow[t]{2}{*}{$\mathrm{mol} / \mathrm{dm}^{3}$ ) } & $331 \mathrm{sh}$ & 7.2 & $322 \mathrm{sh}$ & 2.37 & 265 & 3.16 & $329 \mathrm{sh}$ & 3.4 & $326 \mathrm{sh}$ & 6.12 & $330 \mathrm{sh}$ & 6.5 & 269 & 2.74 \\
\hline & 412 & 31.18 & 403 & 29.28 & $\begin{array}{l}\text { w.b } \\
323 \mathrm{sh} \\
414\end{array}$ & 15.1 & 412 & 15.04 & 415 & 28.98 & 413 & 29.72 & $\begin{array}{l}\text { w.b } \\
327 \mathrm{sh} \\
410\end{array}$ & 7.2 \\
\hline $\mathrm{L}_{4}$ & - & - & - & - & 207 & 8.81 & 207 & 7.77 & - & - & - & - & 214 & 4.55 \\
\hline$\left(0-\mathrm{CH}_{3}\right)$, & - & - & - & - & 244 & 3.24 & 244 & 3.24 & - & - & - & - & 246 & 2.8 \\
\hline$\left(1 \times 10^{-4}\right.$ & 274 & 2.19 & 278 & 1.54 & 274 & 2.13 & 274 & 2.13 & 262 & 2.57 & 275 & 2.17 & 274 & 2.11 \\
\hline \multirow[t]{2}{*}{$\mathrm{mol} / \mathrm{dm}^{3}$ ) } & 389 & 9.83 & 387 & 6.77 & 381 & 5.13 & 381 & 5.26 & 389 & 4.65 & 384 & 5.01 & 381 & 5.07 \\
\hline & $440 \mathrm{sh}$ & 4.37 & 440 & 2.82 & $405 \mathrm{sh}$ & 4.3 & $404 \mathrm{sh}$ & 4.3 & $407 \mathrm{sh}$ & 4.65 & 440 & 2.95 & $406 \mathrm{sh}$ & 4.25 \\
\hline $\mathrm{L}_{5}$ & - & - & - & - & 205 & 8.76 & 207 & 10.71 & - & - & - &.- & 215 & 6.88 \\
\hline$(p-\mathrm{N}, \mathrm{N}-$ & 277 & 7.25 & 276 & 6.655 & 272 & 7.35 & 272 & 7.35 & 276 & 6.88 & 276 & 6.88 & 272 & 7.49 \\
\hline$\left.\left(\mathrm{C}_{2} \mathrm{H}_{5}\right)_{2} \mathrm{~N}\right)$ & 324 & 5.405 & $323 \mathrm{sh}$ & 3.67 & $322 \mathrm{sh}$ & 3.21 & $321 \mathrm{sh}$ & 3.22 & $362 \mathrm{sh}$ & 3.225 & $326 \mathrm{sh}$ & 3.225 & $326 \mathrm{sh}$ & 3.03 \\
\hline$\left(2 \times 10^{-4}\right.$ & 453 & 2.725 & 452 & 2.92 & 447 & 2.5 & 445 & 2.63 & 459 & 2.66 & 446 & 2.685 & 435 & 2.80 \\
\hline $\left.\mathrm{mol} / \mathrm{dm}^{3}\right)$ & $555 \mathrm{sh}$ & 1.08 & $551 \mathrm{sh}$ & 1.33 & $551 \mathrm{sh}$ & 1.53 & $552 \mathrm{sh}$ & 1.625 & - & - & - & - & - & - \\
\hline & - & - & - & - & 212 & 46.14 & 214 & 43.14 & - & - & - & - & 215 & 34.7 \\
\hline (Ar = naphthyl), & - & - & - & - & $244 \mathrm{sh}$ & 12.26 & $244 \mathrm{sh}$ & 12.04 & 249 & 20.28 & - & - & $242 \mathrm{sh}$ & 12.88 \\
\hline$\left(5 \times 10^{-5}\right.$ & 276 & 17.64 & 276 & 17.28 & 269 & 10.52 & 268 & 10.26 & 272 & 20.2 & 275 & 19.96 & 270 & 11.24 \\
\hline \multirow[t]{2}{*}{$\mathrm{mol} / \mathrm{dm}^{3}$ ) } & $337 \mathrm{sh}$ & 7.26 & $339 \mathrm{sh}$ & 6.48 & 340 & 3.38 & $340 \mathrm{sh}$ & 3.26 & $334 \mathrm{sh}$ & 6.46 & $334 \mathrm{sh}$ & 6.18 & $340 \mathrm{sh}$ & 3.62 \\
\hline & $\begin{array}{l}473 \\
\text { br. }\end{array}$ & 17.9 & $\begin{array}{l}466 \\
\text { br. }\end{array}$ & 18.14 & $\begin{array}{l}446 \\
\text { br. }\end{array}$ & 9.82 & 449 br. & 9.62 & $439 \mathrm{br}$. & 18.72 & $443 \mathrm{br}$. & 18.26 & $439 \mathrm{br}$. & 10.26 \\
\hline $\mathrm{L}_{7}$ & - & - & - & - & 207 & 83.6 & 208 & 75.12 & - & - & - & - & - & - \\
\hline$\left(p-\mathrm{NO}_{2}\right)$ & - & - & - & - & 226 & 51.84 & 226 & 51.24 & - & - & - & - & 225 & 53.64 \\
\hline$\left(2.5 \times 10^{-5}\right.$ & 274 & 10.98 & 276 & 10.44 & $274 \mathrm{sh}$ & 8.44 & $274 \mathrm{sh}$ & 7.8 & 276 & 5.85 & 276 & 5.92 & 277 & 9.28 \\
\hline $\mathrm{mol} / \mathrm{dm}^{3}$ ) & 387 & 42.42 & 384 & 41.88 & 372 & 26.92 & 375 & 26.68 & 364 & 16.94 & 364 & 16.46 & 345 & 21.44 \\
\hline $\mathrm{L}_{8}$ & - & - & - & - & 208 & 107.16 & 210 & 105.04 & - & - & - & - & - & - \\
\hline$(\mathrm{H})$ & - & - & - & - & $223 \mathrm{sh}$ & 81.0 & $221 \mathrm{sh}$ & 80.76 & 245 & 18.8 & - & - & 222 & 83.16 \\
\hline$\left(2.5 \times 10^{-5}\right.$ & 282 & 15.32 & 282 & 15.6 & 281 & 15.6 & 279w.b. & 14.76 & 282 & 8.93 & 283 & 8.96 & 278 & 15.76 \\
\hline $\mathrm{mol} / \mathrm{dm}^{3}$ ) & 364 & 27.1 & 363 & 29.84 & $\begin{array}{l}\text { w.b. } \\
357\end{array}$ & 24.88 & 359 & 24.28 & 358 & 14.32 & 358 & 14.3 & $\begin{array}{l}\text { w.b. } \\
358\end{array}$ & 24.8 \\
\hline
\end{tabular}

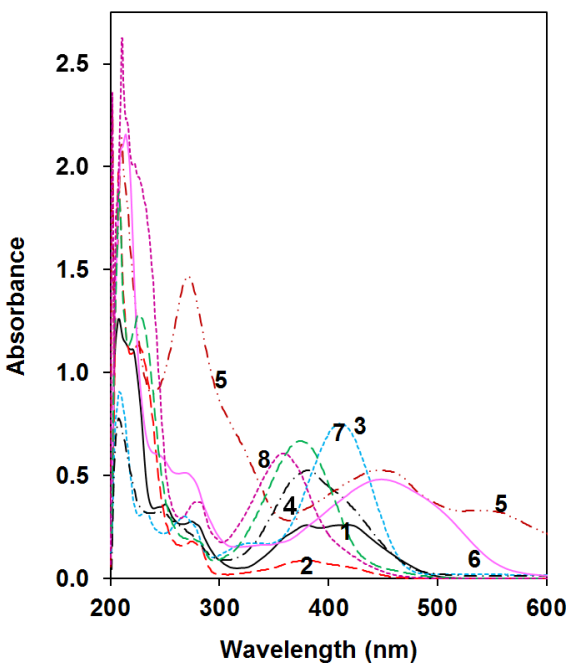

Figure 1. Electronic absorption spectra of $5 \times 10^{-5} \mathrm{~mol} / \mathrm{dm}^{3}$ of 5 -(X-arylazo)2,6-diamino-4-pyrimidinol in ethanol, $\mathrm{X}=p$-OH (1); $p$ - $\mathrm{HSO}_{3}$ (2); o-COOH (3); naphthyl (6); $1 \times 10^{-4} \mathrm{~mol} / \mathrm{dm}^{3}$ of compound, $\mathrm{X}=o-\mathrm{CH}_{3}(4) ; 2 \times 10^{-4} \mathrm{~mol} / \mathrm{dm}^{3}$ of compound, $\mathrm{X}=p-\mathrm{N}\left(\mathrm{C}_{2} \mathrm{H}_{5}\right)_{2}(5)$ and $2.5 \times 10^{-5} \mathrm{~mol} / \mathrm{dm}^{3}$ of compounds, $\mathrm{X}=p$ $\mathrm{NO}_{2}(7) ;-\mathrm{H}(8)$.
Thus, it can be suggested that these two bands are due to $\pi \rightarrow \pi^{*}$ transitions with considerable CT character i.e. intramolecular CT transitions. Such CT seems to originate from the aryl moiety to the pyrimidine ring which is characterized ray accepting character. The existence of more than one CT band was in line with previously observed in spectra of similar compounds [41,42]. This behavior can be expectantly on the basis that these compounds exist mainly in the hydroxy azoquiniod hydrazone tautomeric equilibrium, such equilibrium can be represented in Scheme 2.

The splitting of CT band is also observed during the studies of the effect of aqueous buffer solutions of varying $\mathrm{pH}$ 's on the spectra of compounds under studied $\mathrm{L}_{1}, \mathrm{~L}_{2}, \mathrm{~L}_{4}, \mathrm{~L}_{5}$ and $\mathrm{L}_{7}$. Therefore, the first split band located at $321-382 \mathrm{~nm}$ is due to the structure of the hydrazoquinone, since it was reported that the absorption due to the hydrazone form appears as a shoulder on the short-wavelength side [43]. The second split observed in the 404-449 $\mathrm{nm}$ region is assigned to a $\pi \rightarrow \pi^{*}$ transition within the azo form of the compounds.

The second split show increasing in its absorbance and red shifted by increasing $\mathrm{pH}$ of the medium more than 7.0 whereas the first one is still unaffected. These are in agreement with the behavior reported for similar azo compounds [44-48] and indicate $\pi$-electrons of the $\mathrm{N}=\mathrm{N}$ group is influenced by intramolecular CT involving the lone pair of tertiary nitrogen atom. 

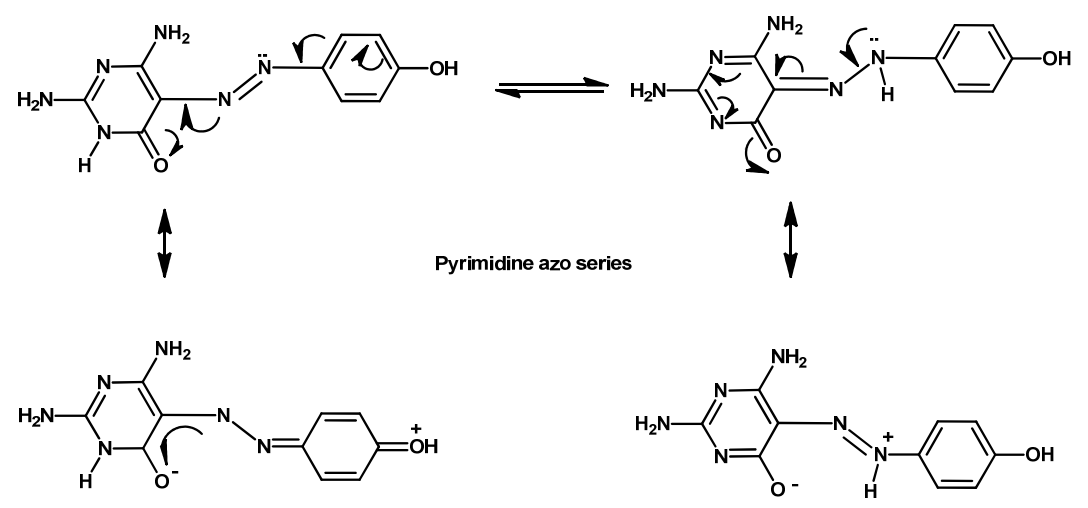

Scheme 2

The appearance of the hydrazo form at shorter wavelength relative to that of the azo form can be explained on the basis that in the hydrazo form the $\pi$-electron delocalization is somewhat restricted relative to the azo compounds [49-51].

The data reported in Table 2 indicate that absorbance of the two split bands are generally affected by the nature of substituent $\mathrm{X}$ of the phenyl moiety which is in agreement with the previously reported that the electronegative substituent will stabilize the azo form i.e., it increases the double bond character of $-\mathrm{N}=\mathrm{N}$ - resulting in the high molar absorptivity of the second split band.

Examination of the results reveals that the position and the molar extinction coefficient of the CT band are quite sensitive to the mesomeric interaction of the substituent X. It is evident from the results that electron donating substituent causes an increase in $\lambda_{\max }$ of the CT band $\left(\mathrm{X}=p-\mathrm{N}\left(\mathrm{C}_{2} \mathrm{H}_{5}\right)_{2}\right)$. This is due to the increase of the electron density of the azo nitrogen atom, resulting in an increase in the contribution of the polar structure to the ground state. This will lead to delocalization of $\pi$-electrons of the $\mathrm{N}=\mathrm{N}$ group and consequently easier CT is expected. On the other hand, in compounds having an electron accepting substituents $\left(\mathrm{X}=p-\mathrm{NO}_{2}\right)$, the CT band is located at higher wavelength than that in case of unsubstituented compounds. This behavior can be discussed on the base that under the influence of the strong electron accepting substituent $\mathrm{X}$, a strong $\mathrm{H}$-bonded chelate ring is established in the hydrazo form of the compound under study as represented schematically in Scheme 3.

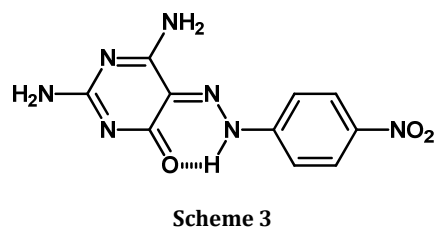

This type of the interaction between the hydrazo hydrogen and the $\mathrm{C}=\mathrm{O}$ oxygen atom will result in leaving residual negative charge on the hydrazo nitrogen and positive charge on the $\mathrm{C}=0$ oxygen atom. Thus, the observed red shift in the spectra of $p-\mathrm{NO}_{2}$ derivative can be ascribed to CT transition within the hydrogen-bonded ring, which behaves as donoracceptor conjugate system. Accordingly, the electron accepting substituent will result in an easier CT interaction within the chelate ring i.e. low excitation energy is required.

The compounds displayed only a single main CT band as fairly intense in polar and non-polar solvents. The appearance of this band at shorter wavelengths than that expected for azo compounds, can be interpreted on the base that the compounds under investigation exist mainly in the hydrazone form in solution which having a limited electronic path [52]. Further, since the spectra of true azo compounds in EtOH are characterized by low excitation energy $n-\pi^{*}$ band $(\sim 400 \mathrm{~nm})$ [53], the absence of this band in the spectra of these compounds studied confirm the presence of these compounds in true hydrazone form. This assignment agrees with the previously reported for structurally related compounds [54].

Moreover, intramolecular CT band in these compounds are located at longer wavelengths than that in the other azo compounds. This is due to the high electron donating character of $\mathrm{NH}_{2}$ groups attached the pyrimidine moiety of azo compounds, as well as, the higher aromatic character of the pyrimidine ring which causes a forced planarity of compound and facilitates the CT to take place within the pyrimidine ring thus leading to the observed high $\lambda$ max values. It is evident from the results that the intramolecular $\mathrm{CT}$ band for $\mathrm{L}_{3}\left(\mathrm{X}=o^{-}\right.$ $\mathrm{COOH}, \lambda=412 \mathrm{~nm}$ ) has higher molar extinction coefficient ( $\varepsilon_{\max }$ $=15.04 \times 10^{3} \mathrm{~mol}^{-1} \cdot \mathrm{dm}^{3}$ ) than those of the other derivative. Based on the previously suggestion that the phenyl ring moiety may be rotated out of plane of the rest of azo compound $[55,56]$, it is expected that two intramolecular H-bond can be formed in compound $\mathrm{L}_{3}$ (Scheme 4).<smiles></smiles><smiles>Nc1nc(N)c2c(n1)O[CH]N1C2=NOC(=O)c2ccccc21</smiles>

Scheme 4

This behavior will result in high electron density on the oxygen atom of $o-\mathrm{COOH}$ group which leads to forced planarity of the compound and in turn facilitates the intramolecular CT transition.

\subsection{Electronic absorption in pure organic solvent}

The electronic absorption spectra of compounds $\left(\mathrm{L}_{1}-\mathrm{L}_{8}\right)$ are recorded in two classes of organic solvents, namely solvents which are either hydrogen bond acceptors or donors (amphiprotic solvents) as $\mathrm{MeOH}, \mathrm{EtOH}, \mathrm{CHCl}_{3}$ and aprotic solvents capable of acting as hydrogen bond acceptors (DMSO, DMF and $\mathrm{CCl}_{4}, \lambda_{\max }(\mathrm{nm})$ and $\varepsilon_{\max }\left(\mathrm{mol}^{-1} \mathrm{~cm}^{2}\right)$ values of different bands obtained in these solvents are collected in Table 2 . The given data reveal that the UV bands are little influenced by changing the solvent properties which confirms the local $\pi \rightarrow \pi^{*}$ nature of transition leading to these types of bands. The listed results show that, the $\lambda_{\max }$ of the $n \rightarrow \pi^{*}$ transition for studied azo pyrimidines is located at higher wavelength than other 
pyrimidines. This is due the expected higher aromatic character of 2,6-diamino-4-pyrimidinol ring. Consequently, the excitation of n-electrons of the hetero nitrogen, di- $\mathrm{NH}_{2}$ groups and $\mathrm{C}=0$ oxygen or nitrogen atoms of the azo group to antibonding $\pi^{*}$ orbital is easier. The data indicate that the $n \rightarrow \pi^{*}$ transition appeared as shoulder of relatively high extinction coefficient in aprotic solvent viz. DMSO and DMF relative to that in protic solvent $\mathrm{CHCl}_{3}$. This supports its $\mathrm{n} \rightarrow \pi^{*}$ assignment, since in protic media the n-electrons are involved in intramolecular hydrogen bonding and consequently their excitation is difficult due to their blocking, by proton transferred from protic solvent molecules.

Moreover, the $n \rightarrow \pi^{*}(268-279 \mathrm{~nm})$ band is appeared as defined shoulder in some studied compounds ( $\mathrm{L}_{6}$ ) or weak broad in the others $\left(\mathrm{L}_{3}\right.$ and $\mathrm{L}_{8}$ ). This can be considered as indication of the existence of these compounds in strong intramolecular $\mathrm{H}$-bond within their hydrazo form. The formation of this H-bond gives stable six-membered cycles which can be broken only by strongest H-bond acceptor solvents used in this work as DMSO and DMF.

The most interesting effects of changing the solvents polarities are observed with the main longer broad band. In general, this band exhibits an appreciable red shift in it $\lambda_{\max }$ as the polarity of the medium is increased. This behavior indicates that the excited state of these compounds is more polar than their ground state and thus, this red shift can be ascribed to stabilization of the polar excited state as the polarity of the solvent increased, i.e., lower excitation energy is required in DMSO or DMF relative to EtOH.

On the other hand, although $\mathrm{CHCl}_{3}$ and $\mathrm{CCl}_{4}$ are characterized by smaller dielectric constants than EtOH, the visible band shows a small blue shifted in its $\lambda_{\max }$ in $\mathrm{EtOH}$ compared to that of $\mathrm{CHCl}_{3}$ or $\mathrm{CCl}_{4}$. This shift can be explained on the basis of amphiprotic character of EtOH, i.e., in alcohol molecules the $\mathrm{OH}$ group can behave as proton donors or acceptors toward the hydrazo NH-N group through H-bonding (Scheme 5) [57].

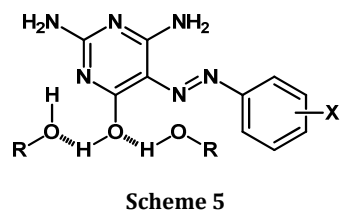

These two types of bonding would compensate each other, indicating that the small blue shift observed in alcohol is the net effect of increased solvent polarity.

Moreover, the visible spectra of $p-\mathrm{N}_{(}\left(\mathrm{C}_{2} \mathrm{H}_{5}\right)_{2}$ derivative in DMSO, DMF, ETOH and $\mathrm{MeOH}$ comprise a new band that occurs at around 551-555 nm, indicating that another tautomer would become dominant in such a solvent. Thus, the new band can be interpreted on the basis that the hydrazo hydrogen is capable of association with the polar solvent through intermolecular $\mathrm{H}$ bonded solvated molecular complexes. Accordingly, it is expected to increase in conjugation length and therefore, the absorption is red shifted in DMSO (or DMF) (Scheme 6).

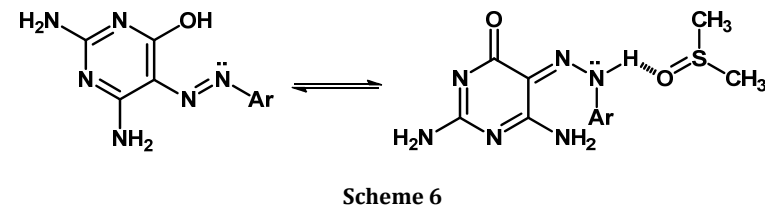

The longer visible band shows a red shift and higher intensity as the polarity of the medium increase. This confirms the CT nature of the band and ascribed to the stabilization of the polar excited state this transition by the polar solvent molecules. The location of the CT band in non-polar and in polar solvents indicates that the subject compounds are in an azo-hydrazone tautomeric equilibrium.

DMSO $>$ DMF $>\mathrm{CHCl}_{3}>\mathrm{CCl}_{4}>\mathrm{C}_{6} \mathrm{H}_{12}$

Moreover, the stabilization of the polar excited state of the intermolecular CT transition by high polar solvents DMSO or DMF adds another factor for the low excitation energy of this band in these polar solvents, relative to non-polar solvents [58].

\subsection{Spectra in mixed organic solvent}

The possibility of the formation of a H-bonded solvated molecular complex between the molecules of $\mathrm{L}_{2}\left(\mathrm{X}=p\right.$ - $\left.\mathrm{HSO}_{4}\right)$, $\mathrm{L}_{6}\left(\mathrm{Ar}=\right.$ Naphthyl), $\mathrm{L}_{7}\left(\mathrm{X}=p-\mathrm{NO}_{2}\right)$ and proton acceptors DMF and DMSO is studied in polar-non polar mixed organic solvents.

The intermolecular solute-solvent interaction forces can be non-specific, such as ion-dipole, dipole-dipole, dipole-induced dipole and specific, such as H-bonding or electron donoracceptor complexation between the solvents $n$-donor and the solute $\pi$-acceptor. Such interaction tends to alter the energy difference between the ground and excited states of the absorbing species. Thus, solvent effects on the absorption spectra of the solute can be used to provide information about solute-solvent interactions. One of the most used ways to elucidate the type of interaction is the use of binary mixtures of solvents. This is based on the fact that one solvent component can be strongly interacted with a solute than the other solvent component. The H-bond formation between DMF and the 5(naphthylazo)-2,6-diamino-4-pyrimidinol can be represented schematically in Scheme 7.

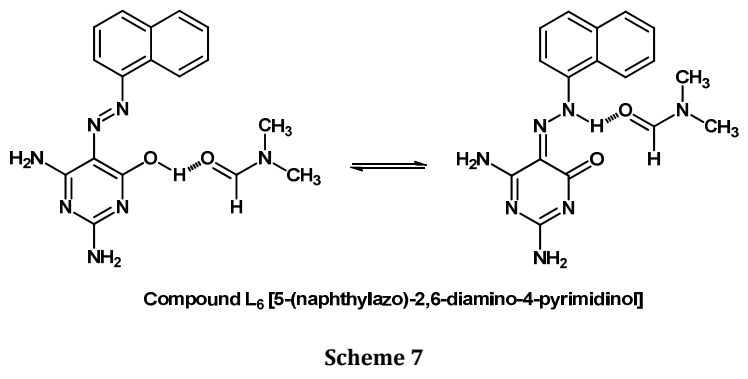

A fine isosbestic points are observed $\left(\mathrm{L}_{2}\right.$ at 352 and $456 \mathrm{~nm}$ and $L_{6}$ at $450 \mathrm{~nm}$ and $\mathrm{L}_{7}$ at $375 \mathrm{~nm}$ ) are represented in Figures 2-4. These isosbestic points indicate the existence of equilibrium between H-bonded and the free molecules. The presence of one isosbestic point in all studied systems clearly indicates the 1:1 solute-solvent $\mathrm{H}$-bond formation. The plot of the absorbance values of the intermolecular CT band against the molarities or mole fraction of DMSO or DMF, exhibits a typical dissociation curves of S-shape. This can be considered as a convincing evidence for the formation of solute-solvent complex.

The values of the formation constant values $\left(\mathrm{K}_{\mathrm{f}}\right)$ of the formed molecular complex are determined from the variation of absorbance with increasing the polar solvent concentration at given wavelength [59]. The mean values of $\mathrm{K}_{\mathrm{f}}$ in all systems investigated and the corresponding $\Delta \mathrm{G}$ values are reported in Table 3. Thus, the equilibrium attained between the H-bonded and the free solute molecules can be represented as follows.

$\mathrm{S}_{\text {(solute) }}+\mathrm{nDMF}_{\text {(solvent) }} \rightleftharpoons \mathrm{S} \ldots . .(\mathrm{DMF})_{\mathrm{n}}$

For which,

$\mathrm{K}_{\mathrm{f}}=\frac{\left[\mathrm{S} \ldots . .(\mathrm{DMF})_{\mathrm{n}}\right]}{[\mathrm{S}][\mathrm{DMF}]^{\mathrm{n}}}$ 
Table 3. Cumulative data obtained for the arylazopyrimidine derivatives in mixed organic solvents.

\begin{tabular}{|c|c|c|c|c|c|}
\hline Compounds & System & $\log K_{f}$ & $\mathbf{K}_{\mathrm{f}}$ & $-\Delta \mathrm{G}$ at $27^{\circ} \mathrm{C}(\mathrm{Kcal} / \mathrm{mol})$ & $\lambda_{\max }(\mathrm{nm})$ \\
\hline \multirow[t]{4}{*}{$\mathrm{L}_{2}\left(\mathrm{x}=p-\mathrm{HSO}_{3}\right)$} & $\mathrm{DMSO}_{-} \mathrm{CHCl}_{3}$ & 0.156 & 1.43 & 0.215 & 384 \\
\hline & DMSO-CCl 4 & 0.306 & 2.02 & 0.423 & 385 \\
\hline & $\mathrm{DMF}^{-\mathrm{CHCl}_{3}}$ & 0.198 & 1.58 & 0.274 & 387 \\
\hline & $\mathrm{DMF}_{-} \mathrm{CCl}_{4}$ & 0.234 & 1.71 & 0.322 & 384 \\
\hline \multirow[t]{2}{*}{$\mathrm{L}_{6}(\mathrm{Ar}=$ naphthyl $)$} & DMSO-CHCl ${ }_{3}$ & 0.496 & 3.13 & 0.685 & 463 \\
\hline & DMF-CHCl ${ }_{3}$ & 0.516 & 3.28 & 0.713 & 475 \\
\hline \multirow[t]{4}{*}{$\overline{\mathrm{L}_{7}\left(\mathrm{x}=p-\mathrm{NO}_{2}\right)}$} & DMSO-CHCl 3 & 0.443 & 2.77 & 0.611 & 389 \\
\hline & $\mathrm{DMSO}^{-\mathrm{CCl}_{4}}$ & 0.272 & 1.87 & 0.376 & 388 \\
\hline & DMF- $\mathrm{CHCl}_{3}$ & 0.495 & 3.13 & 0.685 & 383 \\
\hline & $\mathrm{DMF}_{-\mathrm{CCl}_{4}}$ & 0.303 & 2.01 & 0.419 & 383 \\
\hline
\end{tabular}

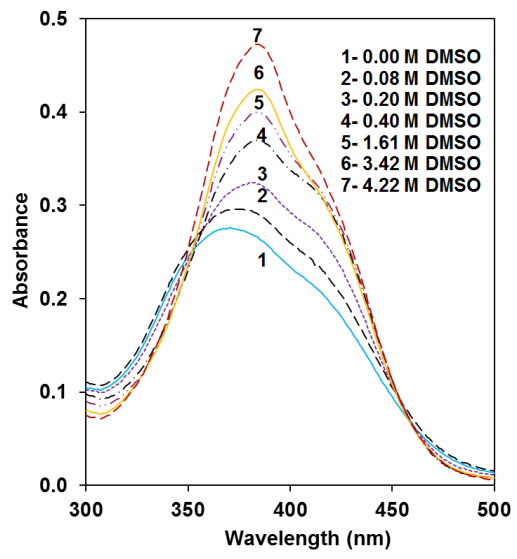

Figure 2. Electronic absorption spectra of $1.5 \times 10^{-4} \mathrm{~mol} / \mathrm{dm}^{3}$ of compound, $\mathrm{L}_{2}\left(\mathrm{x}=p-\mathrm{HSO}_{3}\right)$, in DMSO-CHCl 3 mixtures.

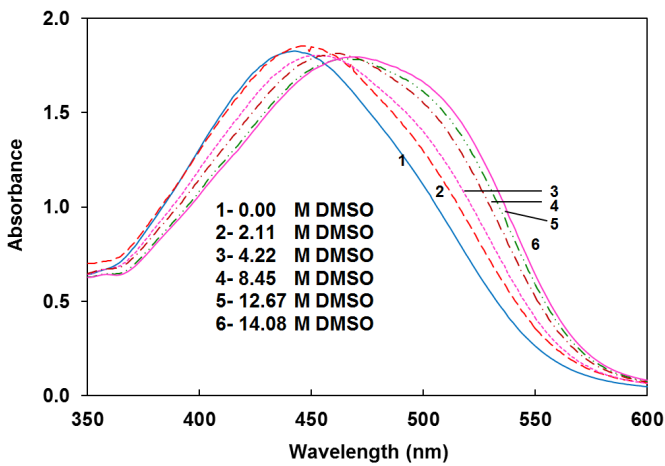

Figure 3. Electronic absorption spectra of $2.0 \times 10^{-4} \mathrm{~mol} / \mathrm{dm}^{3}$ of compound, $\mathrm{L}_{6}(\mathrm{Ar}=$ naphthyl$)$, in DMSO- $\mathrm{CHCl}_{3}$ mixtures.

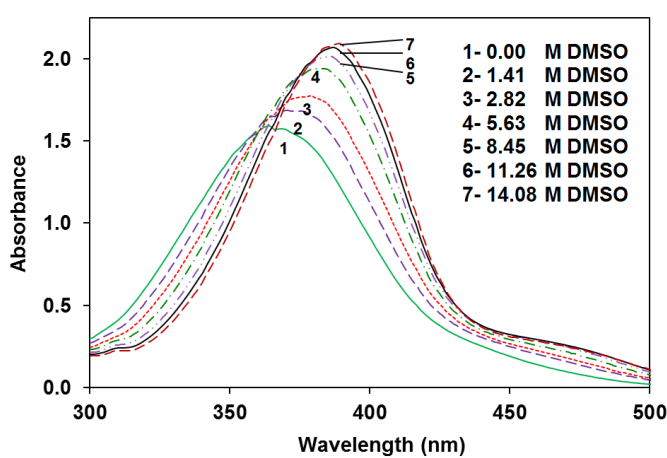

Figure 4. Electronic absorption spectra of $1.0 \times 10^{-4} \mathrm{~mol} / \mathrm{dm}^{3}$ of compound, $\mathrm{L}_{7}\left(\mathrm{x}=p-\mathrm{NO}_{2}\right)$, in DMSO- $\mathrm{CHCl}_{3}$ mixtures. where (n) is the number of associated solvent molecules.

If $\mathrm{C}_{0}$ is the original concentration of the solute, $\mathrm{C}_{S}$ its equilibrium concentration, $\mathrm{C}_{\mathrm{S}}$....DMF is the concentration of the molecular complex formed, $\mathrm{C}_{\mathrm{DMF}}$ is the equilibrium concentration of DMF, then

$$
\mathrm{K}_{\mathrm{f}}=\frac{\mathrm{C}_{\mathrm{S}} \ldots \cdot(\mathrm{DMF})_{\mathrm{n}}}{\mathrm{C}_{\mathrm{S}} \cdot\left[\mathrm{C}_{\mathrm{DMF}}\right]^{\mathrm{n}}}
$$

Substituting the concentration by absorbance values, then

$\mathrm{K}_{\mathrm{f}}=\frac{\mathrm{A}_{(\mathrm{S} \ldots \mathrm{DMF})_{\mathrm{n}}} / \varepsilon_{(\mathrm{S} \ldots \mathrm{DMF})_{\mathrm{n}}} \cdot 1 / \ell}{\mathrm{A}_{\mathrm{S}} / \varepsilon_{\mathrm{S}} \cdot 1 / \ell} \cdot \frac{1}{\left[\mathrm{C}_{\mathrm{DMF}}\right]^{\mathrm{n}}}$

where, $(\ell)$ is the bath length and equal $1.0 \mathrm{~cm}$, thus

$$
\mathrm{K}_{\mathrm{f}}=\log \frac{\mathrm{A}_{(\mathrm{S} \ldots \mathrm{DMF})_{\mathrm{n}}}}{\mathrm{A}_{\mathrm{S}}}+\log \frac{\varepsilon_{\mathrm{S}}}{\varepsilon_{(\mathrm{S} \ldots \mathrm{DMf})_{\mathrm{n}}}}-\frac{1}{\mathrm{n}} \log \mathrm{C}_{\mathrm{DMF}}
$$

If the absorbance of the solute in less polar solvent corresponding to the absorption of the solvated molecular complex, then the following equation could be derived [58].

$\log \mathrm{C}_{\mathrm{DMF}}=\log \mathrm{K}_{\mathrm{f}}+\frac{1}{\mathrm{n}} \log \frac{\mathrm{A}-\mathrm{A}_{\min }}{\mathrm{A}_{\max }-\mathrm{A}}$

where $\mathrm{A}=$ absorbance in the mixed solvent mixture, $\mathrm{A}_{\min }=$ absorbance in low polarity solvent, $A_{\max }=$ absorbance in high polarity solvent.

The plot of Log A-Amin $/ A_{\max }-A$ vs. Log $C_{D M F}$ yield a linear relation with slope $=1 / n$. The $\log \mathrm{K}_{\mathrm{f}}$ value is equal to the value of Log $C_{D M F}$ at $\log A-A_{\min } / A_{\max }-A$ equal zero.

Further support for H-bond formation can be obtained from the data of heat formation $(\Delta \mathrm{G})$ of the solvated molecular complex which is calculated using the relation:

$\Delta \mathrm{G}=-\mathrm{RT} \ln \mathrm{K}_{\mathrm{f}}$

The results suggest that the molecular complex is formed through the formation of 1:1 intramolecular H-bond in Scheme 8. The solute thus solvated becomes practically insensitive to further changes in the mixture composition. Moreover, the $\mathrm{K}_{f}$ values in $\mathrm{CCl}_{4}$ show higher value than that in $\mathrm{CHCL}_{3}\left(\mathrm{~L}_{2}\right)$. This suggested that, competitive donor-solvent complexes in $\mathrm{CHCl}_{3}$ may be the reason for increasing $\mathrm{K}_{\mathrm{f}}$ values $\mathrm{CCl}_{4}$. The electronic absorption spectra of the studied compounds $\left(\mathrm{L}_{1}-\mathrm{L}_{8}\right)$ in buffer solutions reveals that the absorption spectra of $1.0 \times 10^{-4}$ $\mathrm{mol} / \mathrm{dm}^{3}$ of 5-(4-hydroxy-phenylazo)-2,6-diamino-4-pyrimidinol $\left(\mathrm{L}_{1}, \mathrm{X}=p-\mathrm{OH}\right)$ within the $\mathrm{pH}$ range 2.39-12.84 (Figure 5) display four absorption bands. The absorption spectral data of various prototropic species are listed in Table 4. 
Table 4. Ionisation constant values, $\lambda_{\text {iso }}$ and $\lambda_{\max }$ of cationic, neutral and ionic form for 5 -(X-phenylazo)pyrimidine derivatives

\begin{tabular}{|c|c|c|c|c|c|c|c|c|}
\hline \multirow[t]{2}{*}{ Compounds } & \multirow[t]{2}{*}{$\mathbf{p K}_{\mathrm{NH}}$} & \multirow[t]{2}{*}{$\mathbf{p K}_{\mathrm{NH} 2}$} & \multirow[t]{2}{*}{ pK $K_{\text {Sub. }}$} & \multirow[t]{2}{*}{$\mathbf{p K}_{\mathrm{OH}}$} & \multirow[t]{2}{*}{$\lambda_{\text {iso }}$} & \multicolumn{3}{|l|}{$\lambda_{\max }$} \\
\hline & & & & & & Cationic & Neutral & Anionic \\
\hline $\mathrm{L}_{1}(\mathrm{X}=p-\mathrm{OH})$ & 2.50 & 4.70 & 7.40 & 10.75 & 329,419 & 438 & 419,380 & 390,446 \\
\hline $\mathrm{L}_{2}\left(\mathrm{X}=p-\mathrm{HSO}_{3}\right)$ & 2.50 & 4.58 & 5.22 & 9.50 & 390 & 408 & 381 & 390 \\
\hline $\mathrm{L}_{3}(\mathrm{X}=o-\mathrm{COOH})$ & 3.10 & 3.95 & 5.60 & 9.30 & 334,394 & 412 & 400 & 375 \\
\hline $\mathrm{L}_{4}\left(\mathrm{X}=o-\mathrm{CH}_{3}\right)$ & 2.60 & 4.90 & - & 10.60 & 340,403 & 421 & 413,373 & 372 \\
\hline $\mathrm{L}_{5}\left(\mathrm{X}=p-\mathrm{N}_{(}\left(\mathrm{C}_{2} \mathrm{H}_{5}\right)_{2}\right)$ & 2.60 & 5.35 & - & 10.90 & 395,502 & 503 & 466 & 316,450 \\
\hline $\mathrm{L}_{6}(\mathrm{Ar}=$ Naphthyl $)$ & 2.63 & 5.80 & - & 9.60 & 510,646 & 513 & 460 & 443 \\
\hline $\mathrm{L}_{7}\left(\mathrm{X}=p-\mathrm{NO}_{2}\right)$ & 2.85 & 4.75 & - & 8.35 & - & 389 & 387 & 385 \\
\hline $\mathrm{L}_{8}(\mathrm{X}=\mathrm{H})$ & 2.90 & 5.35 & & 10.30 & 275,405 & 411 & 362 & 350 \\
\hline
\end{tabular}

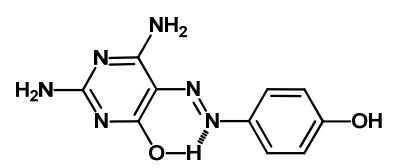

Intramolecular H-bonding form

Scheme 8

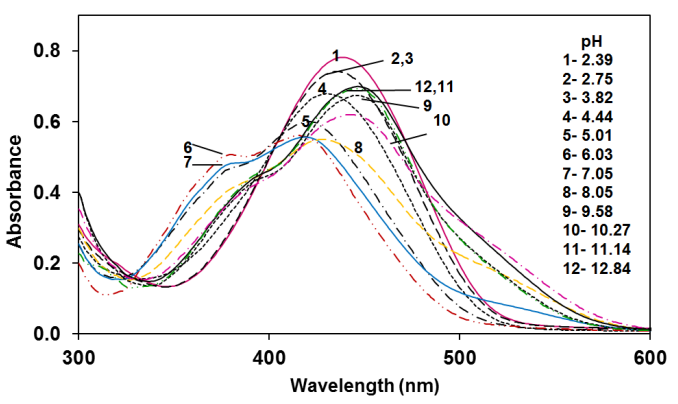

Figure 5. Electronic absorption spectra of $1.0 \times 10^{-4} \mathrm{~mol} / \mathrm{dm}^{3}$ of compound, $\mathrm{L}_{1}\left(\mathrm{X}={ }_{p}-\mathrm{OH}\right)$, in aqueous universal buffer solutions.

In solution of low $\mathrm{pH}$ values, (2.39-3.82) a broadband observed at $\lambda=438 \mathrm{~nm}$ which is presumable due to the presence of dication $\left(\mathrm{H}_{4} \mathrm{~L}^{2+}\right)$ and monocationic $\left(\mathrm{H}_{3} \mathrm{~L}^{+}\right)$form. In this acids medium, it is suggested that both tertiary nitrogen and $\mathrm{NH}_{2}$ groups of pyrimidine moiety can be protonated. This protonation leads to an increase in the acceptor character of the compound and hence increase in CT interaction is expected. When $\mathrm{pH}$ increase, the intensity of this band is decreased and suffered a blue shift, as a result of stepwise deprotonation of cationic specie to neutral species. At pH from 5.01-7.05, this band is splited into double band at 419 and $380 \mathrm{~nm}$. The appearance of an isosbestic point at $329 \mathrm{~nm}$ is due to an equilibria existing in solution between the hydrazo and azo forms of monocationic reagent at this $\mathrm{pH}$ range. Therefore, the first split at shorter wavelength of the double parts band is attributed to the hydrazo form while the second one at longer wavelength is due to CT within the azo form. The second split suffer a red shift as $\mathrm{pH}$ increase due to the elimination of another proton leading to the formation of anionic (HL) species which have an absorption band at $\lambda=446 \mathrm{~nm}$. This band acquires a little red shift due to the appearance of dianonic ( $L^{2-}$ ) species. An isosbestic point at $\lambda=419 \mathrm{~nm}$ is appeared due to the equilibria existing in solution between the neutral form and both anionic and dianionic forms of the reagent. The various protoropic reactions occurring in solution of different $\mathrm{pH}$ ranges can be represented in Scheme 9.

The electronic absorption spectra of $1.0 \times 10^{-4} \mathrm{~mol} / \mathrm{dm}^{3}$ of 5 [arylazo(2,6-diamino-4-pyrimidinol)]-4-sulphonic acid (compound $\mathrm{L}_{2}, \mathrm{X}=p-\mathrm{HSO}_{3}$ ) in aqueous universal buffer solutions of varying $\mathrm{pH}$ 's from $2.39-12.84$ is represented in Figure 6 . The recorded spectra comprise mainly one band in the visible region at $408 \mathrm{~nm}$, which is apparently due to the dicationic $\left(\mathrm{H}_{4} \mathrm{~L}^{2+}\right)$ species of this compound. The intensity of this band decreases as $\mathrm{pH}$ increases as a result of deprotonation of both amino groups in the pyrimidine ring at $\mathrm{pH}$ range $2.39-3.83$ and $\mathrm{pH}$ range 3.83-5.01, this band became broad at 387-400 nm range due to deprotonation of the amino groups in the pyrimidine ring. An isosbestic point at $\lambda=392 \mathrm{~nm}$ is appeared due to the equilibria existing in solution between monocatinic and neutral forms of the compound. At $\mathrm{pH}$ rang 5.01-8.05, the intensity of this band decreases and undergoes a little blue shift due to the formation of monoanionic from as elimination of proton from sulfonic group. At $\mathrm{pH}$ from 8.05-9.58, the intensity of the band at $375 \mathrm{~nm}$ increases and undergoes a red shift as a result of formation of intramolecular H-bond.

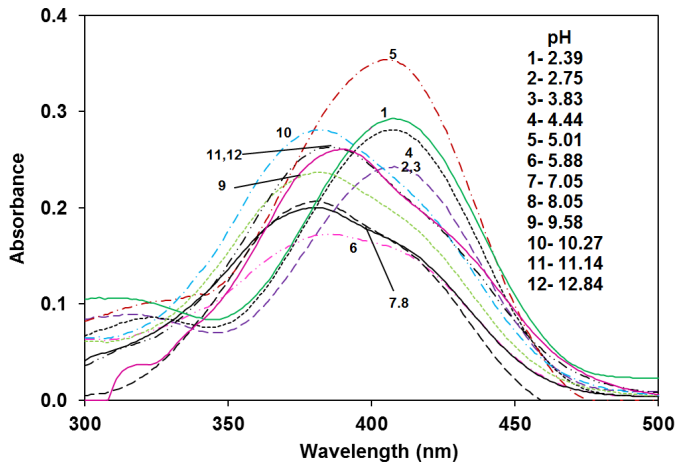

Figure 6. Electronic absorption spectra of $1.0 \times 10^{-4} \mathrm{~mol} / \mathrm{dm}^{3}$ of compound, $\mathrm{L}_{2}\left(\mathrm{X}=p-\mathrm{HSO}_{3}\right)$, in aqueous universal buffer solutions.

The spectra of $0.5 \times 10^{-4} \mathrm{~mol} / \mathrm{dm}^{3}$ of 5-[arylazo-(2,6diamino-4-pyrimidinol)]-2-carboxylic acid ( $\mathrm{L}_{3}, \mathrm{X}=o$ - $\mathrm{COOH}$ ) solutions in aqueous buffer solution at different $\mathrm{pH}$ 's are represented in Figure 7. The band observed at $\lambda=412 \mathrm{~nm}$, in low $\mathrm{pH}$ values $(\mathrm{pH}<3.46)$ is presumably due to the presence of dicationic $\left(\mathrm{H}_{4} \mathrm{~L}^{2+}\right)$ form of azo reagent such protonation takes place at the tertiary nitrogen or $\mathrm{NH}_{2}$ group of pyrimidine ring. As $\mathrm{pH}$ increases, the intensity of this band is decreased and became broad band, as a result of stepwise deprotonation of dicationic species to monocationic species At $\mathrm{pH}$ rang 3.464.44 , the intensity of this band increases and accompanied by another shoulder band at $\lambda=490 \mathrm{~nm}$ as a result of the formation of neutral species as a result of deprotonation of $\mathrm{H}_{2} \mathrm{~L}$ species. At the $\mathrm{pH}$ rang 4.44-8.05, the band at $412 \mathrm{~nm}$ suffers a very little shift to $400 \mathrm{~nm}$ due to transformation of the neutral species to the monoanionic species. The observed increase in its absorbance in this $\mathrm{pH}$ rang can be attributed to the rupdure of the intramolecular $\mathrm{H}$-bond formed between the $\mathrm{o}-\mathrm{OH}$ of the pyrimidine ring and the nitrogen of azo group. At high $\mathrm{pH}(\mathrm{pH}>$ 8.05), a blue shift is clearly appeared to $375 \mathrm{~nm}$ with decreasing in absorbance as dianionic species is formed. A clear isosbestic point at $\lambda=394 \mathrm{~nm}$ is observed which indicating an equilibrium can exist in solution between the monoanionic form and the dianionic form of the reagent. According to the obtained results, it can represent the acid-base equilibria existing in solution for compound $\left(\mathrm{L}_{3}, \mathrm{X}=\mathrm{o}-\mathrm{COOH}\right)$ by the Scheme 10. 

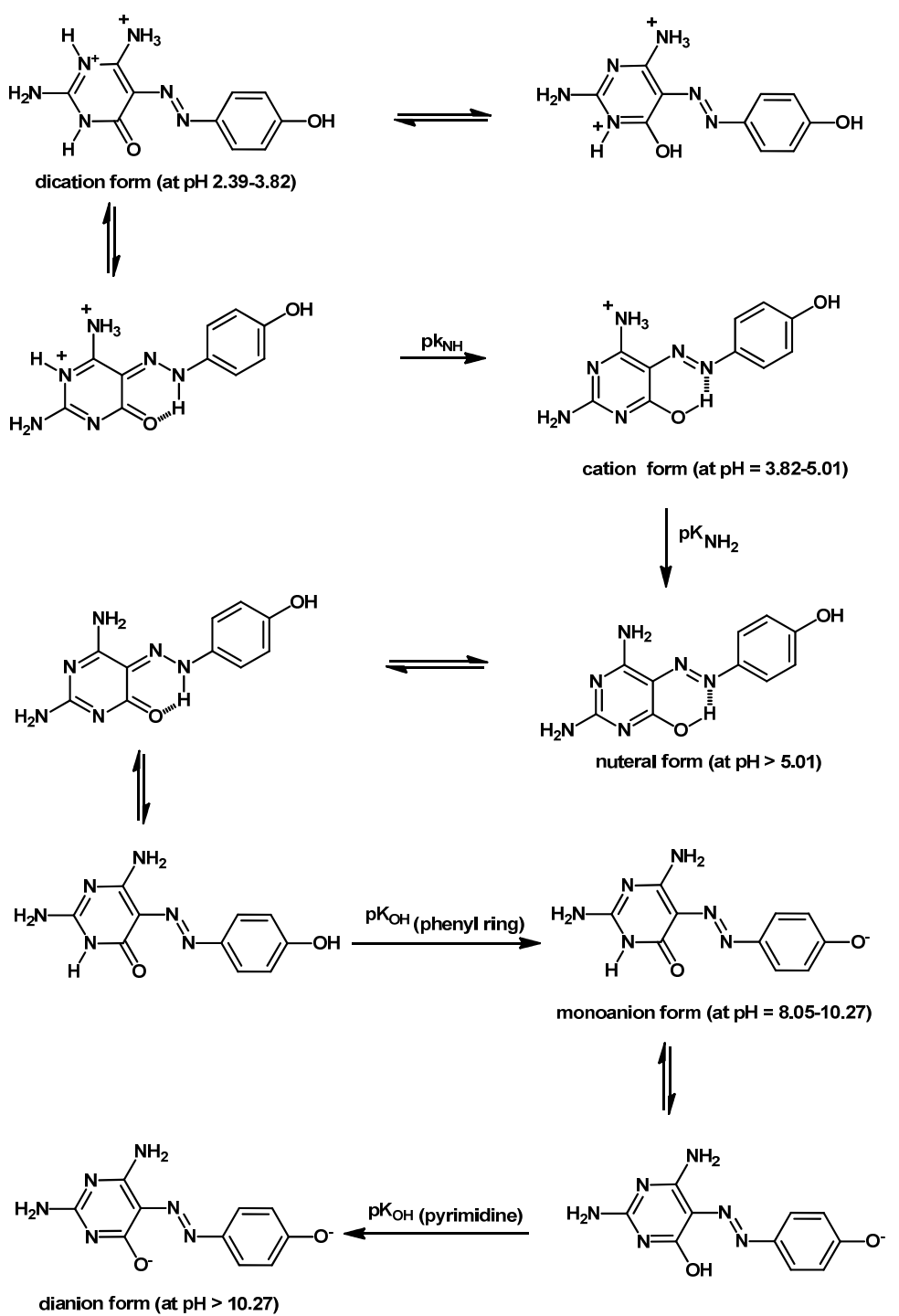

Scheme 9

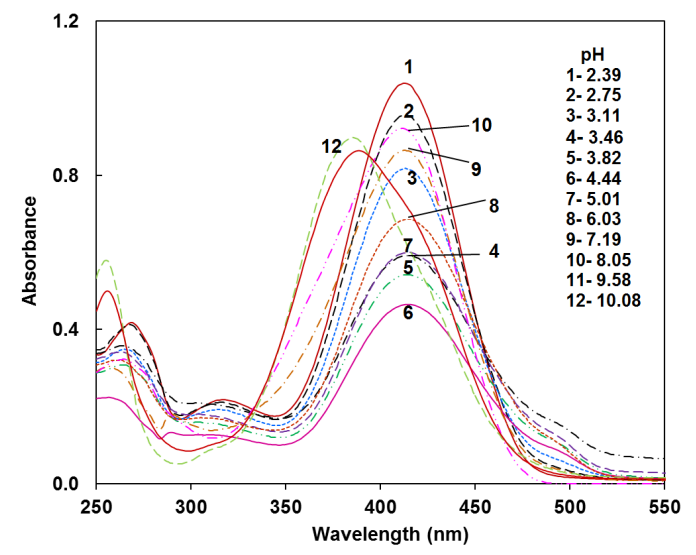

Figure 7. Electronic absorption spectra of $0.5 \times 10^{-4} \mathrm{~mol} / \mathrm{dm}^{3}$ of compound, $\mathrm{L}_{3}(\mathrm{X}=o-\mathrm{COOH})$, in aqueous universal buffer solutions.

The electronic spectra of 5-(2-methylarylazo)-2,6-diamino4-pyrimidinol (compound $\mathrm{L}_{4}, \mathrm{X}=o-\mathrm{CH}_{3}$ ) at various $\mathrm{pH}$ 's values represented in Figure 8. In acidic media $(\mathrm{pH}=2.46-4.44)$ the recorded spectra show a band at $421 \mathrm{~nm}$ which can be attributed to the absorption of dicationic $\left(\mathrm{H}_{3} \mathrm{~L}^{2+}\right)$, such protonated species can take place at tertiary nitrogen or $\mathrm{NH}_{2}$ group of pyrimidine moiety, the intensity of this band decrease as the $\mathrm{pH}$ increase. On increasing the $\mathrm{pH}$ of the medium $\mathrm{pH}>$ 4.44 , the intensity of this band show continuous decrease with gradually blue shift where a band with two parts is exhibited, at $\lambda=413-383 \mathrm{~nm}$ where the whole monocationic form $\mathrm{H}_{2} \mathrm{~L}^{+}$is transformed to neutral form HL. A clear isosbestic point at $\lambda=$ $403 \mathrm{~nm}$ is noticed as a result of transformation of neutral form HL in azo form to neutral form HL in hydrazo form.

At $\mathrm{pH}$ rang 10.27-12.56, the band with two parts are mixed and formed one band at $382 \mathrm{~nm}$. This band is apparently due to the absorption by monoanionic species of $\left(\mathrm{L}_{4}, \mathrm{X}=o-\mathrm{CH}_{3}\right)$. Its intensity increase as the $\mathrm{pH}$ increases and there is an isosbestic point at $340 \mathrm{~nm}$ due to the equilibria between the neutral form and monoanionic form.

On careful examination of the spectral behaviour in varying $\mathrm{pH}$ 's mentioned above, it is noticeable that the reported compounds $\left(\mathrm{L}_{1}-\mathrm{L}_{4}\right)$ have similar prototropic reactions as they have an analogous structure. 
<smiles>C=C1ONC2(Nc3ccccc31)Nc1nc(N)nc(N)c1O2</smiles><smiles>C=C</smiles>

dication form (at $\mathrm{pH}<3.46)$

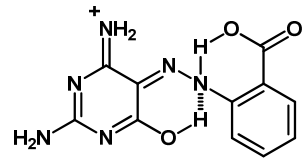<smiles>C1CCC2[Pb]CCC2C1</smiles>

cation form (at pH 3.46-4.44)

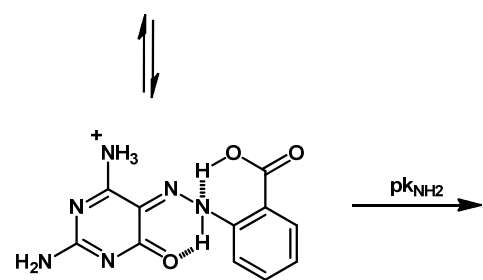<smiles>Nc1nc(N)c2c(n1)N1OC(=O)c3ccccc3N1N2O</smiles><smiles>Nc1nc(N)c2c(n1)ONC21Nc2ccccc2C(=O)O1</smiles><smiles>C=C</smiles>

$\mathrm{H}_{2} \mathrm{~N}$

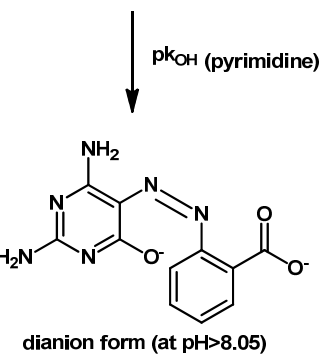

Scheme 10

Therefore, here after we shall focus our discussion on the general feature of $\mathrm{L}_{5}-\mathrm{L}_{8}$ which have nearly identical spectral behavior. The effect of $\mathrm{pH}$ values on the electronic absorption spectra of the compounds $\mathrm{L}_{5}-\mathrm{L}_{8}\left(\mathrm{X}=p-\mathrm{N}\left(\mathrm{C}_{2} \mathrm{H}_{5}\right)_{2}, \mathrm{Ar}=\right.$ Naphthyl, $\mathrm{X}=p-\mathrm{NO}_{2}$ and $-\mathrm{H}$, respectively) are represented in Figures 912. Generally, the recorded spectra of all compounds studied within $\mathrm{pH}$ range 2.39-12.84 display several prototropic species. In solution of low $\mathrm{pH}$ values (2.39-3.82), the visible spectrum exhibits an absorption band with $\lambda_{\max }$ at $389-513 \mathrm{~nm}$ region, presumably due to the absorption of dicationic form of the compounds studied. In this acidic medium, it is suggested that in diaminopyrimidine derivatives studied both tertiary nitrogen, as well as, the $\mathrm{NH}_{2}$ groups can be protonated. On decreasing the acidity of the medium, the main band is blue shifted and increases in its intensity. This is due to transformation of the dicationic species to the monocationic species. On further increase of the $\mathrm{pH}$ from 3.82-7.59, a continuous blue shift is observed as the neutral species is formed. At higher $\mathrm{pH}>7.59$, the band suffers a decrease in its intensity (compounds ( $\mathrm{L}_{5}$ and $\mathrm{L}_{8}$ ) or suffers an increase in its intensity (compounds $\mathrm{L}_{6}$ and $\mathrm{L}_{7}$ ) as the transformation of monoanionic species ( $\mathrm{L}^{-}$) as the elimination of proton from $o$ hydroxy group of pyrimidine moiety.

The basicity and acidity constants $\left(\mathrm{pK}_{\mathrm{NH}}, \mathrm{pK}_{\mathrm{NH} 2}\right.$ and $\left.\mathrm{pK}_{\mathrm{O}-\mathrm{OH}}\right)$ of pyrimidine ring for the compounds studied, as well as, the acidity constants of substituent in the phenyl ring $\left(\mathrm{L}_{1}, \mathrm{pK}_{\mathrm{p}}-\mathrm{OH}_{;}\right.$ $\mathrm{L}_{2}, \mathrm{pK}_{\mathrm{HSO}} ; \mathrm{L}_{3}, \mathrm{pK}_{\mathrm{o}-\mathrm{COOH}}$ ) were calculated from the electronic spectra at different $\mathrm{pH}$ values using the methods which described before. The mean $\mathrm{pK}$ values corresponding to the different ionization steps are listed in Table 4 . The values obtained by the three methods are in close agreement with each other. 


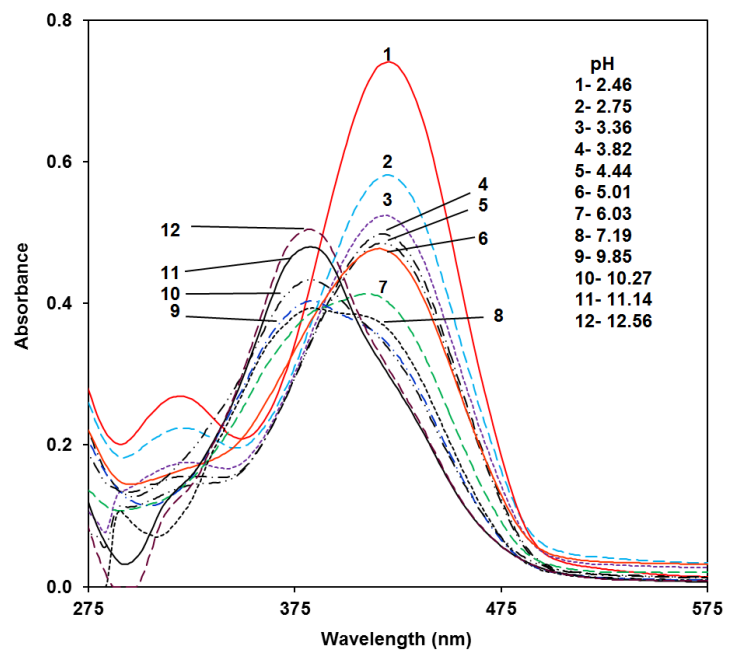

Figure 8. Electronic absorption spectra of $1.0 \times 10^{-4} \mathrm{~mol} / \mathrm{dm}^{3}$ of compound, $\mathrm{L}_{4}\left(\mathrm{X}=o-\mathrm{CH}_{3}\right)$, in aqueous universal buffer solutions.

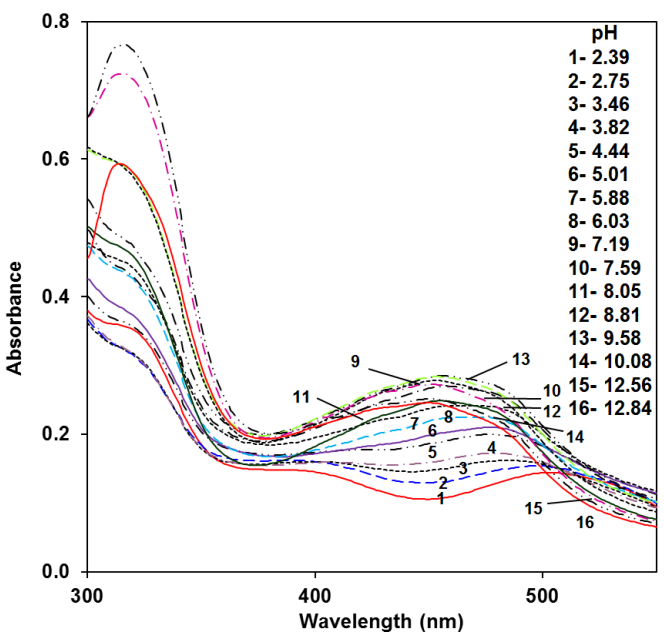

Figure 9. Electronic absorption spectra of $1.0 \times 10^{-4} \mathrm{~mol} / \mathrm{dm}^{3}$ of compound, $\mathrm{L}_{5}\left(\mathrm{X}=p-\mathrm{N}\left(\mathrm{C}_{2} \mathrm{H}_{5}\right)_{2}\right)$, in aqueous universal buffer solutions.

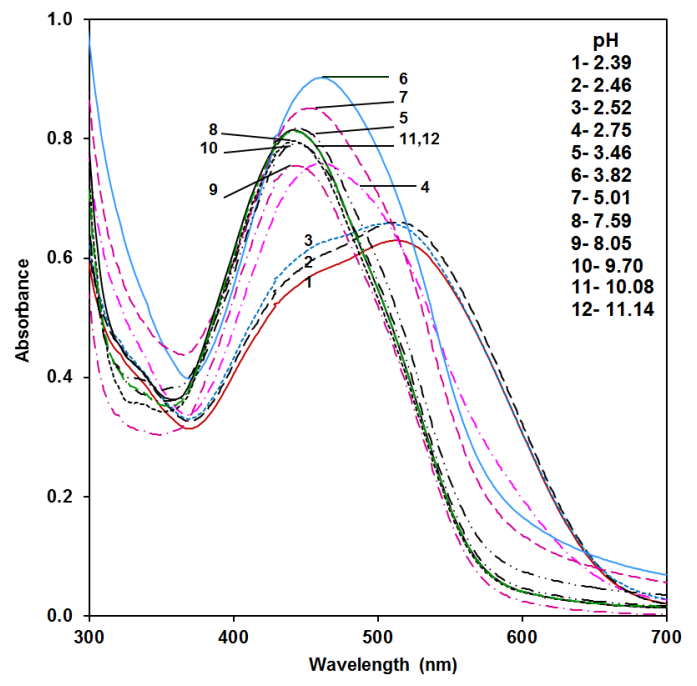

Figure 10. Electronic absorption spectra of $1.0 \times 10^{-4} \mathrm{~mol} / \mathrm{dm}^{3}$ of compound, $\mathrm{L}_{6}(\mathrm{X}=A r$-naphthyl $)$, in aqueous universal buffer solutions.

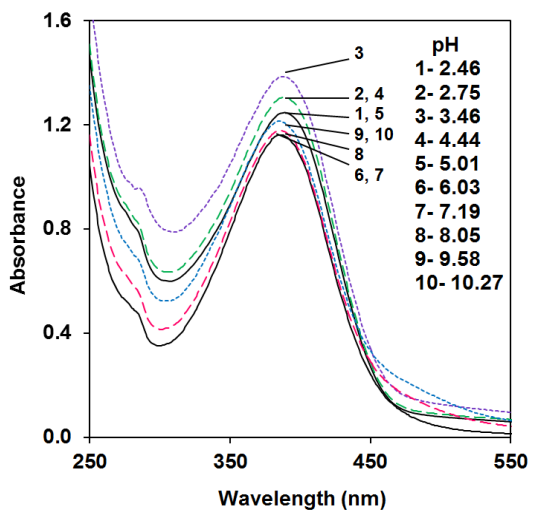

Figure 11. Electronic absorption spectra of $0.7 \times 10^{-4} \mathrm{~mol} / \mathrm{dm}^{3}$ of compound, $\mathrm{L}_{7}\left(\mathrm{X}={ }_{\mathrm{p}}-\mathrm{NO}_{2}\right)$, in aqueous universal buffer solutions.

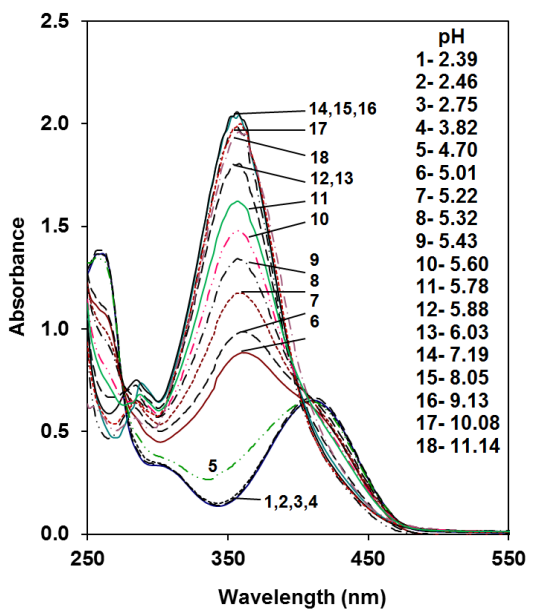

Figure 12. Electronic absorption spectra of $1.0 \times 10^{-4} \mathrm{~mol} / \mathrm{dm}^{3}$ of compound, $\mathrm{L}_{8}(\mathrm{X}=\mathrm{H})$, in aqueous universal buffer solutions.

From the data obtained following conclusions can be made. It is clear from the various prototropic reactions, listed in Table 4 , that the protonation of the studied compounds can take place at tertiary nitrogen atom and the amino group. It is well established that if $\pi \rightarrow \pi^{*}$ is the lowest single states then tertiary nitrogen atom become more basic than $\mathrm{NH}_{2}$ group $[60,61]$. This behaviour indicates the tertiary nitrogen atom gets protonated first followed by $\mathrm{NH}_{2}$ group $[62,63]$. A similar behaviour is also observed in case of amino quinolone [64], where the $\mathrm{pK}$ of $\mathrm{NH}_{2}$ group is extremely low, so that the ring nitrogen is protonated first. This behavior is in accordance with the suggested prototropic reaction occurring in our compounds. From previous reports [65], it is known that for pyridine, a $\mathrm{pK}=5.1$ is detected, while for aniline, the $\mathrm{pK}$ is 4.6 and when the two rings (pyridine and aniline) occurring in a same molecule, the $\mathrm{pK}$ of $\mathrm{NH}_{2}$ decrease and that of heterocyclic nitrogen increase. This effect depends on the electron-withdrawing capacity of the heterocyclic nitrogen and the electron-donating effect of the $\mathrm{NH}_{2}$ group.

The pKa values increases in compounds of electron donating character of substituent $\left(\mathrm{X}=p-\mathrm{OH}, o-\mathrm{CH}_{3}\right.$ and $p-\mathrm{N}$ $\left.\left(\mathrm{C}_{2} \mathrm{H}_{5}\right)_{2}\right)$. This is due to the easier intramolecular CT transition toward the pyrimidine ring. This is in turn increases the base strength (increase pKa) of these compounds, i.e., the basicity $(\mathrm{pK})$ of the pyrimidine ring increases on changing substituent $X$ according to following sequence. 
$p-\mathrm{N}\left(\mathrm{C}_{2} \mathrm{H}_{5}\right)_{2}>p-\mathrm{OH}>o-\mathrm{CH}_{3}>-\mathrm{H}>$ naphthy $>$ $p-\mathrm{HSO}_{3}>o-\mathrm{COOH}>p-\mathrm{NO}_{2}$

The protonation constants of the $\mathrm{NH}_{2}$ group of the azopyrimidine studied are somewhat lower compared to diaminopyrimidine derivatives 5.3-4.9 [66]. This indicates that the studied compounds are more acidic than the parent compound. This probably attributed to stabilization of the compound by delocalization of charge over the whole molecule [67]. This effect of substituent is more apparent in case of p$\mathrm{NO}_{2}$ compound which shows lower $\mathrm{pK}$ values (higher ionization constant). This can be attributed to the antagonizing character of $\mathrm{NO}_{2}$ group on the CT interaction that takes place in solute molecule. Accordingly, the strong -I effect of the $\mathrm{NO}_{2}$ group results in decreasing the electron density on the nitrogen atom of hydrazo group on hetero ring. This leads to decrease the $\mathrm{N}-\mathrm{H}$ band strength. This leads to facilitate the liberation of hydrogen ion.

In the studied compounds, due to the weak basicity of the $\mathrm{N}=\mathrm{N}$ group [68], it can act as proton acceptor which can accept proton at very low $\mathrm{pH}$ values $\sim 2.0$ [69]. Thus, its $\mathrm{pK}$ values cannot be determined in our work. In addition, the nonequivalence of $\mathrm{pK}$ values of hetero nitrogen $\mathrm{N}_{(1)}$ and $\mathrm{N}_{(3)}$ could be attributed to the possible $\mathrm{H}$-bonding interaction between one of the two $\mathrm{NH}_{2}$ group and the adjacent hetero- $\mathrm{N}$ atom belong to pyridine ring. Moreover, the higher pKa values of $\mathrm{COOH}$ group than that of unsubstituted benzoic acid itself (pKa $=4.2$ ] [59] due to the expected involvement of this group in intramolecular $\mathrm{H}$-bonding with the proton acceptor $\mathrm{N}=\mathrm{N}$ group, this results to decrease the acidity of $\mathrm{COOH}$ group.

The high values of $\mathrm{p} K_{\mathrm{a}}$ values of pyrimidine $o-\mathrm{OH}$ group can be attributed to the existence of an interaction between this group and the nitrogen lone pair electrons of the azo group through and the intramolecular $\mathrm{H}$-bonding. This in turn results in difficult liberation of the $o-\mathrm{OH}$ proton. On the other hand, it is obvious that the pKa $o-\mathrm{OH}$ value is affected by the substituent in the phenyl ring. Its $\mathrm{pK}$ values are low in compounds having electron withdrawing character probably due to the decrease in the $\mathrm{N}=\mathrm{N}$ basicity which leads to weakening the intramolecular $\mathrm{H}$-bond and result in easier liberation of $\mathrm{o}-\mathrm{OH}$ proton.

\section{Conclusions}

The spectra of ligands in pure organic solvents of different polarities, in mixed organic solvents and in buffer solutions of different $\mathrm{pH}$ 's have been determined. All compounds can be attributed to the localization of $\pi$-electrons in pyrimidine ring and in benzene ring respectively. The main visible band is assigned to $\pi \rightarrow \pi^{*}$ transition involving $\pi$-electronic system of the whole compounds, associated with intramolecular charge transfer. Such CT seems to originate from the aryl moiety to the pyrimidine ring which is characterized by accepting character. This behavior can be explained on the basis that these compounds exist mainly in the hydroxyazo-quinoid hydrazon tautomeric equilibrium. The higher values of $\mathrm{pK}_{\mathrm{a}} \mathrm{O}-\mathrm{OH}$ values of pyrimidine $\mathrm{o}-\mathrm{OH}$ group can be due to the existence of an interaction between this group and the lone pair electrons of nitrogen atom in the azo group through the intramolecular $\mathrm{H}$ bonding. The $\mathrm{p} K_{\mathrm{a}} \mathrm{O}-\mathrm{OH}$ value is affected by the substituent in the phenyl moiety.

\section{Acknowledgement}

We are thankful to the Department of Chemistry, Aswan Faculty of Science, Aswan University, Aswan, Egypt for support of the work.

\section{References}

[1]. Klyansundaram, K.; Gratzel, M. J. Coord. Chem. 1998, 177, 347-414.
[2]. Uma, R.; Palaniandavar, M.; Butcher, R. J. J. Chem. Soc., Dalton Trans. 1996, 2061-2066.

[3]. Nagao, H.; Ooyama, D.; Hirano, T.; Naoi, H.; Shimada, M.; Sasaki, S. Nagao, N.; Mukaida, M.; Takao, O. Inorg. Chim. Acta 2001, 320, 60-66.

[4]. Argazzi, R.; Bignozzi, C. A.; Hasselmann, G. M.; Meyer, G. J. Inorg. Chem. 1998, 37, 4533-4537.

[5]. Constable, E. C. Coord. Chem. Rev. 1989, 93, 205-223.

[6]. Zrenner, R.; Stitt, M; Sonnewald, M.; Boldt, R. Annu Rev Plant .2006, 57, 805-863.

[7]. Colacio, E.; Dominguez-Vera, J. M.;Costes ,J.P.; Kivekas, R.; Laurent, J. P. Ruiz, J.; Sundberg, M. J. Inorg. Chem. 1992, 31, 774-778

[8]. Cookson, P. D.; Tiekimk, R. T. J. Chem. Soc., Dalton Trans. 1993, 259 263.

[9]. Hung, C. Y.; Wang, T. L.; Jang, Y.; Kim, W. Y.; Schmehl, R. H.; Thummel, R. P. Inorg. Chem. 1996, 35, 5953-5956.

[10]. Real, J. A.; Munoz, M. C.; Andres, E.; Granier, T.; Gallios, B. Inorg. Chem. 1994, 33, 3587-3594.

[11]. Yamamoto, T.; Zhou, Z.; Kanbara, T.; Shimura, M.; Kizu, K.; Maruyama, T.; Nakamura, Y.; Fukuda, T.; Lee, B.; Ooba, N.; Tomaru, S.; Kurihara, T.; Kaino, T.; Kubota, K.; Sasaki, S. J. Am. Chem. Soc. 1996, 118, 1038910399.

[12]. Hansongnern, K.; Tempiam, S.; Liou, J. C.; Liao, F. L.; Lu, T. H. Anal. Sci. 2003, 19, 13-14

[13]. Masoud, M. S.; Mostafa, A. Z.; Ahmed, R. H.; Abd El Moneim, N. H. Molecules 2003, 8, 430-438.

[14]. Buzykin, B. I.; Sorokin, M. Y.; Krivolapov, D. B.; Gubaidullin, A. T.; Litvinov, I. A. Chem. Heterocyc. Compd. 2002, 38, 1348-1356.

[15]. Tsupak, E. B.; Shevchenko, M. A.; Tkachenko, Y. N.; Nazarov, D. A. Russ. J. Org. Chem. 2002, 38(6), 880-888.

[16]. Kaupp, G.; Herrmann, A.; Schmeyers, J. Chem. Eur. J. 2002, 8(6), 13951406.

[17]. Moreno, J. M.; Ruiz, J.; Dominguez-Vera, J. M.; Calacio, E. Inorg. Chim. Acta 1993, 208(1), 111-115.

[18]. Masoud, M. S.; Ghonaim, A. K.; Ahmed, R. H.; Mahmoud, A. A.; Ali, A. E. Z. Phys. Chem. 2001, 215(4), 531-542.

[19]. Masoud, M. S.; El-Enein, S. A.; Obeid, N. A. Z. Phys. Chem. 2001, 215(7), 867-881.

[20]. Abdel-Razik, H. H.; Refat, Hala, M.; Zaki, M. E. A. Heterocycl. Commun. 2001, 7(3), 263-270.

[21]. Kletskii, M. E.; Tsupak, E. V. Chem. Heterocyc. Compd. 2001, 37(10), 1238-1240.

[22]. Madkour, H. M. F.; Mahmoud, M. R.; Nassar, M. H.; Habashy, M. M. Molecules 2000, 5, 746-755.

[23]. Gupta, S. P.; Sharma, S.; Goel, R. K. Spectrochim. Acta A 1986, 42, 10 1163-1171.

[24]. Goel, R. K. Spectrochimica Acta A 1984, 40, 723-732.

[25]. Roubsnd, D. B.; Kister, J.; Bonscasse, L.; Metzer, J. Spectrosc. Lett. 1981, 14,431-439.

[26]. Scudero, F. E.; Mo, O.; Yamez, M. J. Chem. Soc., Perkin Trans. 1983, 11, 1735-1739.

[27]. Martin, R. B.; Mariam, Y. H. Met. Ions Biol. Syst. 1979, 8, 57-124.

[28]. Hug, W.; Tinocoo, J. J. J. Am. Chem. Soc. 1973, 95, 2803-2813.

[29]. Amrallah, A. H.; Abdalla, N. A.; El-Haty, E. Y. J. Chin. Chem. Soc. Taip 2006, 53(3), 697-706.

[30]. Britton, H. T. S. In Hydrogen ions, $4^{\text {th }}$ Edi., Chapmann and Hill, London, 1954, pp. 217.

[31]. Douheret, G. Bull. Soc. Chim. Fr. 1967, 11, 1409-1413.

[32]. Hammam, A. M.; Issa, R. M.; Amin, S. A.; Dissouki, H. Gazz. Chim. Ital. 1979, 109, 351-355.

[33]. Issa, Y. M.; Abdel-Gani, N. T.; Aboudan, M. O. J. Indian Chem. Soc. 1983, 60, 24-26.

[34]. Berrie, A. H.; Hampson, P.; Longworth, S. W.; Mathias, A. J. Chem. Soc B 1968, 1308-1310.

[35]. Dessouki, H. A.; Killa, H. M.; Zaghloul, A. Spectrochim. Acta A 1986, 42, 631-635.

[36]. Sen, D.; Bhowmik, S.; Sengupta, P. J. Indian Chem. Soc. 1986, 63, 420424.

[37]. Nakamura, M.; Sakanashi, Y.; Chikushi, H.; Kai, F.; Sato, S.; Uchikawa, S. Talanta 1987, 34, 369-371.

[38]. Staab, H. A.; Brettschneider, H.; Breunner, H. Chem. Ber. 1970, 103, 11011-11016.

[39]. Ahmed, Z. A.; Atta, F. M.; Abdalla, M. A.; Abdelmonem, M. E.; Metwally, S. Spectrochim. Acta A 1989, 45, 699-703.

[40]. Kantlehner, J.; Mezger, E. V.; Stoyanov, S. M.; Zakeeruddin, M. Chem Rev. 1980, 33, 251-266.

[41]. Masoud, M. S.; Zaki. Z. M.; Ismail. F. M.; Mohamed, A. K. J. Phys. Chem. 1994, 185(2), 223-227.

[42]. Beaton, H. G.; Willey, G. R.; Drew, M. G. B. J. Chem. Soc., Perkin Trans. 1987, 2, 469-470.

[43]. Hodgson, D. M.; Gibbs, A. R.; Drew; M. G. B. J. Chem. Soc., Perkin Trans. I 1999, 24, 3579-3590.

[44]. Ruiz, J.; Calacio, E.; Lopez-Gonzalez, J. D.; Sundberg, M.; Kivekas, R. J. Chem. Soc., Dalton Trans. 1990, 9, 2747-2752.

[45]. Issa, I. M.; Mahmoud, R. M.; Temerik, Y. M. Z. J. Phys. Chem. 1973, 253 289-306.

[46]. Navas, D. J. Photochem. Photobiol. Chem. 990, 53, 41-50. 
[47]. Candida, M.; Vaz, T. A.; Frauto Dasilva, J. J. J. Inorg. Nucl. Chem. 1981, $43,1573-1578$

[48]. Amin, A. S.; Mohammed, T. Y. Talanta 2001, 54(4), 611-620.

[49]. Singh, I.; Saini, R. Talanta 1994, 41(12), 2173-2175.

[50]. Swaminathan, M.; Dogra, S. K. J. Am. Chem. Soc. 1983, 105, 6220-6223.

[51]. Shulman; S. G. J. Pharm. Sci. 1971, 60, 371-374.

[52]. Mahmoud, M. R.; Ibrahim, S. A.; Hamed, M. M. Spectrochim. Acta A 1983, 39, 924-927.

[53]. Pilpenko, A. T.; Savransky, L. I. Talanta 1987, 34, 77-86.

[54]. Borges, C. P. F.; Tabak, M. Spectrochim. Acta A 1994, 50(6), 1047-1054.

[55]. Gutierrez, M. D.; Lopez, R.; Romero, M. A.; Salas, M. Can. J. Chem. 1988, 66, 249-255.

[56]. Amrallah, A. H.; Abdalla, N. A.; El-Haty, E. Y. Monatsh. Chem. 1997, 128, 1073-1084

[57]. Pati, S. The chemistry of hydrazo, azo and azoxy groups, Part 2, JohnWilley and Sons, London, 1975, pp. 845-854.

[58]. Haselbach, E. Helv. Chim. Acta 1970, 53, 1526-1526.

[59]. Lurie, J., Hand book of analytical chemistry, Mir publishers, Moscow, Translated the Russian by Bobrov, N. 1974, pp. 275.

[60]. Foster, R.; Thomson, T. T. Faraday Soc. 1962, 58, 860-868.

[61]. Bhaskar, K. R.; Gosavi, R. K.; Rao, C. N. R. T. Faraday Soc. 1966, 31, 333-343.

[62]. Mishra, A. K.; Dogra, S. K. J. Photochem. 1985, 6, 81-88.

[63]. Zeynel, S. Arkivoc 2009, 7, 42-57.

[64]. Seferoglu, Z.; Ertan, N. Cent. Eur. J. Chem. 2008, 6, 81-88.

[65]. Shulman, S. G. ; Kovi ,P.J.; Young, J. F. J. Pharm. Sci. 1973, 62, 11971199.

[66]. Gutierrez, M. D.; Lopez, R.; Romero, M. A.; Salas, M. Can. J. Chem. 1988, 66, 249-255.

[67]. Abed, N. M.; Nashed, B.; Fahmy, H. M.; Abdel, A. M. Monatsh. Chem. 1986, 117, 799-803.

[68]. Miyadera T.; Kosower, E. M. J. Med. Chem. 1972, 15(5), 534-537.

[69]. Haselbach, E.; Girault, H.; Bernard, T. Helv. Chim. Acta 1999, 82, 12111222. 